\title{
Method for forecasting pollution of urban areas
}

\author{
Anton Radaev ${ }^{1}$ and Elena Korneeva ${ }^{2, *}$ \\ ${ }^{1}$ Peter the Great St. Petersburg Polytechnic University, St. Petersburg, Russian Federation \\ ${ }^{2}$ Saint Petersburg State University of Architecture and Civil Engineering, St. Petersburg, Russian Federation
}

\begin{abstract}
A model for substantiating the parameters of regression models for a comprehensive indicator of environmental pollution has been developed. A distinctive feature is the separate consideration of the influence of factors of the natural and industrial environment, as well as the linear nature of the interaction of nonlinear variables. The resulting model will allow us to analyze the current state of the environment depending on the quantity and quality of environmental indicators, and also identify critical changes in it. In the urban development industry, this model will help in planning the possibility of placing objects with a high environmental burden in a particular area.
\end{abstract}

\section{Introduction}

The development of urban areas, for the most part, is due to the progressive growth of city-forming industrial enterprises, utilities and transport hubs, affecting the economic, environmental and social components of the city and the country as a whole. With the growth and development of technological progress, the natural environment is experiencing a load on a relative scale, more and more polluting substances enter the environment, contributing to cause geo-ecological instability. Many human activities, and in particular industrial production, produce a huge amount of waste and pollution, which require the development of basic technologies for controlling emissions, processes, implementation and costs of which should be justified by the degree of achieved results [1-3]. In order to answer the question about the state of environmental pollution, it is necessary to conduct systematic observations and assess the technogenic impact on natural objects of urban agglomerations. Many scientists consider the geoecological problems of urban areas, trying to find new forecasting methods and methods for assessing the current situation, under the influence of technological progress [4-9]. Globally, adverse effects on human health and air quality can be considered as a result of anthropogenic activities responsible for economic development and energy dependence [10-14].

Many objects located in or near the city do not fulfill the required environmental safety measures, which entails the accumulation and spread of harmful substances in the surrounding space. All kinds of pollutants accumulate and settle on the surface, getting into bodies of water, groundwater, and also with water and air into the organisms of living beings, which leads to a decrease in the number of natural resources suitable for use, to an increase in the incidence of the population, and as a result a reduction in life expectancy [ 15-18]. In order to suspend the launched process of anthropogenic impact and not aggravate the current situation, it is necessary to look for new methods for predicting the development of environmental pollution from stationary sources and vehicles. The most relevant pollution prediction methods today are monitoring, GIS, mapping, modeling, which allow us to assess the environment with an increase in the number of components [19-27].

Thus, if it is necessary to draw dependencies and find patterns between the actual state of the environment and potential sources of pollution, it is possible to create a new technique based on a mathematical model.

\section{Methods}

This article discusses the methodology of predictive modeling, depending on the number of components of anthropogenic and natural environments. The construction of models is a necessary measure due to the inability to explore a real object in all its complexity. Naturally, the simplification should not concern the most important elements from the point of view of the tasks being solved.

The goal was set as part of the study - to develop a forecast model with which you can compare the quantitative data received from monitoring stations with the actual number of considered objects emitting harmful substances, thereby assessing areas in which objects are harmful that affect the environment and predict the development of urban areas so as not to aggravate the environmental situation.

Initial data and unknown variables for created procedure are specified in Table 1. Calculated characteristics of the procedure are specified in Table 2 .

\footnotetext{
* Corresponding author: linka360639020@yandex.ru
} 
Table 1. Initial data and unknown variables for created procedure.

\begin{tabular}{|c|c|c|c|}
\hline No. & $\begin{array}{c}\text { Name of the initial data } \\
\text { element }\end{array}$ & \begin{tabular}{|l|} 
Meas \\
. unit \\
\end{tabular} & \begin{tabular}{|l|} 
Designation \\
/ expression \\
\end{tabular} \\
\hline 1 & \multicolumn{3}{|l|}{ Initial data } \\
\hline 1.1 & \multicolumn{3}{|l|}{ Initial data for optimization model } \\
\hline 1.1. & \multicolumn{3}{|l|}{ General initial data } \\
\hline $\begin{array}{l}1.1 . \\
1.1\end{array}$ & $\begin{array}{l}\text { Total number of indicators for } \\
\text { natural environment }\end{array}$ & units & $m$ \\
\hline $\begin{array}{l}1.1 . \\
1.2\end{array}$ & $\begin{array}{l}\text { Total number of indicators for } \\
\text { industrial environment }\end{array}$ & units & $n$ \\
\hline $\begin{array}{l}1.1 . \\
1.3\end{array}$ & \begin{tabular}{|l}
$\begin{array}{l}\text { Total number of studied } \\
\text { geographical areas }\end{array}$ \\
\end{tabular} & units & $\bar{D}$ \\
\hline $\begin{array}{l}1.1 . \\
1.4\end{array}$ & $\begin{array}{l}\text { Largest absolute difference of } \\
\text { indicators } \mathrm{Q}^{\mathrm{I}} \text { and } \mathrm{Q}^{\mathrm{N}}{ }_{d}\end{array}$ & \begin{tabular}{|c|} 
conv. \\
units \\
\end{tabular} & $M$ \\
\hline $\begin{array}{l}1.1 . \\
1.5\end{array}$ & $\begin{array}{l}\text { Minimal values of the } \\
\text { coefficients } \mathrm{w}^{\mathrm{I}} d \text { and } \mathrm{w}^{\mathrm{N}}{ }_{d}\end{array}$ & - & $W^{\min }$ \\
\hline $\begin{array}{l}1.1 . \\
1.6\end{array}$ & \begin{tabular}{|l|l|}
$\begin{array}{l}\text { Minimal values of the } \\
\text { coefficients } \mathrm{w}^{\mathrm{I}} d \text { and } \mathrm{w}^{\mathrm{N}}{ }_{d}\end{array}$ & \\
\end{tabular} & - & $W^{\max }$ \\
\hline $\begin{array}{c}1.1 . \\
2\end{array}$ & \multicolumn{3}{|l|}{ Indexes } \\
\hline $\begin{array}{l}1.1 . \\
2.1\end{array}$ & $\begin{array}{l}\text { Index for indicator connected to } \\
\text { natural environment }\end{array}$ & - & $i$ \\
\hline $\begin{array}{l}1.1 . \\
2.2\end{array}$ & $\begin{array}{l}\text { Index for indicator connected to } \\
\text { industrial environment }\end{array}$ & - & $j$ \\
\hline $\begin{array}{l}1.1 . \\
2.3\end{array}$ & $\begin{array}{l}\text { Index for studied geographical } \\
\text { area }\end{array}$ & - & $d$ \\
\hline $\begin{array}{c}1.1 . \\
3\end{array}$ & \multicolumn{3}{|c|}{$\begin{array}{l}\text { Initial data for the indicator connected to natural } \\
\text { (industrial) environment; }\end{array}$} \\
\hline $\begin{array}{l}1.1 . \\
3.1\end{array}$ & $\begin{array}{l}\text { Name of indicator for natural } \\
\text { (industrial) environment }\end{array}$ & - & - \\
\hline $\begin{array}{l}1.1 . \\
3.2\end{array}$ & $\begin{array}{l}\text { Minimal proportion of the } \\
\text { influence coefficient to natural } \\
\text { (industrial) environment }\end{array}$ & - & \\
\hline $\begin{array}{l}1.1 . \\
3.3\end{array}$ & $\begin{array}{l}\text { Maximal proportion of the } \\
\text { influence coefficient to natural } \\
\text { (industrial) environment }\end{array}$ & - & \\
\hline $\begin{array}{c}1.1 . \\
4\end{array}$ & \multicolumn{3}{|c|}{ Initial data for studied geographical area } \\
\hline $\begin{array}{l}1.1 . \\
4.1\end{array}$ & Name of geographical area & - & - \\
\hline $\begin{array}{c}1.1 . \\
5\end{array}$ & \multicolumn{3}{|c|}{$\begin{array}{l}\text { Initial data for the indicator connected to natural } \\
\text { (industrial) environment in geographical area; ; }\end{array}$} \\
\hline $\begin{array}{l}1.1 . \\
5.1\end{array}$ & $\begin{array}{l}\text { Absolute value of the indicators } \\
\text { for natural (industrial) } \\
\text { environment }\end{array}$ & MU* & \\
\hline 1.2 & \multicolumn{3}{|c|}{ Initial data for pollution forecast model } \\
\hline $\begin{array}{c}1.2 . \\
1\end{array}$ & $\begin{array}{l}\text { Index of geographical area to be } \\
\text { considered }\end{array}$ & - & $d^{\circ}$ \\
\hline $\begin{array}{c}1.2 . \\
2\end{array}$ & $\begin{array}{l}\text { Value for the indicator of } \\
\text { natural (industrial) environment } \\
\text { corresponding to present } \\
\text { state** of the geographical area } \\
d^{\circ} ; ;\end{array}$ & MU* & \\
\hline $\begin{array}{c}1.2 . \\
3\end{array}$ & $\begin{array}{l}\text { Value for the indicator of } \\
\text { industrial environment } \\
\text { corresponding to future state of } \\
\text { the geographical area } d^{\circ} ; \text {; }\end{array}$ & MU* & \\
\hline 2 & \multicolumn{3}{|c|}{ Unknown variables of optimization model } \\
\hline
\end{tabular}

\begin{tabular}{|l|l|l|l|}
\hline 2.1 & $\begin{array}{l}\text { Coefficient of influence of the } \\
\text { particular indicator of the } \\
\text { natural (industrial) environment } \\
\text { on the complex indicator; }\end{array}$ & - & \\
\hline 2.2 & $\begin{array}{l}\text { Absolute positive (negative) } \\
\text { deviation of the complex } \\
\text { indicator for industrial } \\
\text { environment from the complex } \\
\text { indicator for natural } \\
\text { environment in geographical } \\
\text { area }\end{array}$ & & \\
\hline 2.3 & $\begin{array}{l}\text { Indicator of excess of indicator } \\
\mathrm{Q}^{\mathrm{I}} \text { related to indicator } \mathrm{Q}_{d}\end{array}$ & - & \\
\hline $\begin{array}{l}\text { Note: } \\
\text { * invidual (in general case) measure unit determined by the } \\
\text { nature of the indicator under consideration } \\
* *\end{array}$ & \\
\hline
\end{tabular}

Table 2. Calculated characteristics for created procedure.

\begin{tabular}{|c|c|c|c|}
\hline No & $\begin{array}{c}\text { Name of the initial } \\
\text { data element }\end{array}$ & \begin{tabular}{|l|} 
Meas \\
. unit
\end{tabular} & Formula \\
\hline 1 & \multicolumn{3}{|c|}{ Calculated characteristics of optimization model } \\
\hline 1.1 & \multicolumn{3}{|c|}{$\begin{array}{l}\text { Calculated characteristics for the indicator connected } \\
\text { to natural (industrial) environment in geographical } \\
\text { area ; ; }\end{array}$} \\
\hline $\begin{array}{c}1.1 \\
.1\end{array}$ & $\begin{array}{l}\text { Normalized value } \\
\text { of the indicator* }\end{array}$ & - & \\
\hline 1.2 & \multicolumn{3}{|c|}{ Calculated characteristics for geographical area ; } \\
\hline $\begin{array}{c}1.2 \\
.1\end{array}$ & $\begin{array}{l}\text { Complex indicator } \\
\text { for natural } \\
\text { (industrial) } \\
\text { environment } \\
\end{array}$ & - & \\
\hline 1.3 & \multicolumn{3}{|c|}{$\begin{array}{l}\text { Calculated characteristics for the indicator connected } \\
\text { to natural (industrial) environment; }\end{array}$} \\
\hline $\begin{array}{c}1.3 \\
.1\end{array}$ & $\begin{array}{l}\text { Value of the } \\
\text { indicator for the } \\
\text { most favorable } \\
\text { region }\end{array}$ & $\mathrm{MU}^{* *}$ & $\begin{array}{l}\text { if increase of the } \\
\text { indicator i(j) determines } \\
\text { a favorable } \\
\text { environmental impact; } \\
\text { otherwise. }\end{array}$ \\
\hline $\begin{array}{c}1.3 \\
.2\end{array}$ & $\begin{array}{l}\text { Value of the } \\
\text { indicator value for } \\
\text { the least favorable } \\
\text { region }\end{array}$ & $\mathrm{MU}^{* *}$ & $\begin{array}{l}\text { if increase of the } \\
\text { indicator } \mathrm{i}(\mathrm{j}) \text { determines } \\
\text { a favorable } \\
\text { environmental impact; } \\
\quad \text { otherwise. }\end{array}$ \\
\hline $\begin{array}{c}1.3 \\
.3\end{array}$ & $\begin{array}{l}\text { Minimal value of } \\
\text { the coefficient of } \\
\text { influence of the } \\
\text { particular indicator } \\
\text { for the } \\
\text { environment on the } \\
\text { complex indicator }\end{array}$ & - & \\
\hline $\begin{array}{c}1.3 \\
.4\end{array}$ & $\begin{array}{l}\text { Maximal value of } \\
\text { the coefficient of } \\
\text { influence of the } \\
\text { particular indicator } \\
\text { for the } \\
\text { environment on the } \\
\text { complex indicator }\end{array}$ & - & \\
\hline 1.4 & \multicolumn{3}{|c|}{ Aggregated calculated characteristics } \\
\hline $\begin{array}{c}1.4 \\
.1\end{array}$ & $\begin{array}{l}\begin{array}{l}\text { The coefficient of } \\
\text { determination of }\end{array} \\
\end{array}$ & - & \\
\hline
\end{tabular}




\begin{tabular}{|c|c|c|c|}
\hline & $\begin{array}{|lr|}\text { the } & \text { complex } \\
\text { indicator } & \text { of } \\
\text { industrial } & \text { (natural) } \\
\text { environment on the } \\
\text { complex } & \text { indicator } \\
\text { of } & \text { natural } \\
\text { (industrial) } & \\
\text { environment } & \\
\end{array}$ & & \\
\hline 2 & \multicolumn{3}{|c|}{$\begin{array}{l}\text { Calculated characteristics for pollution forecast } \\
\text { model }\end{array}$} \\
\hline 2.1 & \multicolumn{3}{|c|}{ 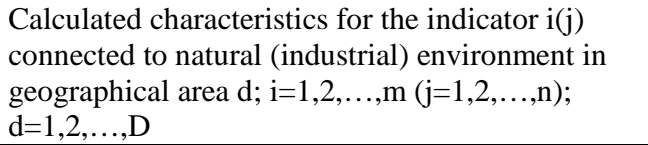 } \\
\hline $\begin{array}{c}2.1 \\
.1\end{array}$ & $\begin{array}{l}\text { Proportion in the } \\
\text { complex indicator } \\
\text { of natural } \\
\text { (industrial) } \\
\text { environment, for } \\
\text { the indicator of } \\
\text { natural (industrial) } \\
\text { environment }\end{array}$ & - & null otherwise \\
\hline 2.2 & \multicolumn{3}{|c|}{$\begin{array}{l}\text { Calculated characteristics for the indicator } \mathrm{i}(\mathrm{j}) \\
\text { connected to natural (industrial) environment }\end{array}$} \\
\hline \begin{tabular}{c|}
2.2 \\
.1
\end{tabular} & \begin{tabular}{|l} 
Average value of \\
proportion in the \\
complex indicator \\
of natural \\
(industrial) r for \\
environment rat \\
particular indicator \\
of natural \\
(industrial) \\
environment
\end{tabular} & - & \\
\hline \begin{tabular}{|c|}
2.2 \\
.2
\end{tabular} & 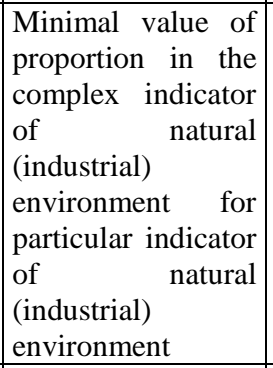 & - & \\
\hline $\begin{array}{c}2.2 \\
.3\end{array}$ & \begin{tabular}{|lrl} 
Maximal value of \\
proportion in & the \\
complex indicator \\
of & natural \\
(industrial) & \\
environment & for \\
particular indicator \\
of & natural \\
(industrial) & \\
environment & \\
\end{tabular} & - & \\
\hline \begin{tabular}{c|c|}
2.2 \\
.4
\end{tabular} & $\begin{array}{l}\text { Normalized value } \\
\text { of the indicator for } \\
\text { the current state of } \\
\text { the geographical } \\
\text { area } d^{\circ} \text { under } \\
\text { consideration } d^{\circ} \\
\end{array}$ & - & \\
\hline \begin{tabular}{c|}
2.2 \\
.5 \\
\end{tabular} & \begin{tabular}{|l|} 
Normalized value \\
the indicator $\mathrm{j}$ of \\
industrial \\
environment \\
corresponding to \\
the future state of \\
the geographical \\
area $d^{\circ}$ under \\
consideration $d^{\circ}$
\end{tabular} & - & \\
\hline
\end{tabular}

\begin{tabular}{|c|c|c|c|}
\hline $\begin{array}{l}2.2 \\
.6\end{array}$ & \begin{tabular}{|lr|}
\multicolumn{2}{|c|}{ Change of absolute } \\
value of indicator \\
for & the \\
geographical & area \\
$d^{\circ}$ & under \\
consideration $d^{\circ}$
\end{tabular} & - & $=$ \\
\hline $\begin{array}{c}2.2 \\
.7\end{array}$ & $\begin{array}{|lr|}\text { Change r } & \text { of } \\
\text { normalized } & \text { value } \\
\text { of indicator for the } \\
\text { geographical } & \text { area } \\
d^{\circ} & \text { under } \\
\text { consideration } d^{\circ}\end{array}$ & - & $=$ \\
\hline $\begin{array}{c}2.2 \\
.8\end{array}$ & $\begin{array}{l}\text { Normalized value } \\
\text { for the indicator } i \\
\text { of natural } \\
\text { environment } \\
\text { corresponding to } \\
\text { the future state of } \\
\text { the geographical } \\
\text { area } d^{\circ} \text { under } \\
\text { consideration } d^{\circ}\end{array}$ & - & \\
\hline $\begin{array}{c}2.2 \\
.9\end{array}$ & $\begin{array}{l}\text { Absolute value for } \\
\text { the indicator } i \text { of } \\
\text { natural } \\
\text { environment } \\
\text { corresponding to } \\
\text { the future state of } \\
\text { the geographical } \\
\text { area } d^{\circ} \text { under } \\
\text { consideration } d^{\circ}\end{array}$ & - & \\
\hline 2.3 & $\begin{array}{l}\text { Calculated characteri } \\
\text { under consideration; }\end{array}$ & & geographical area $d^{\circ}$ \\
\hline $\begin{array}{c}2.3 \\
.1\end{array}$ & $\begin{array}{|ll|}\begin{array}{l}\text { Complex indicator } \\
\text { of natural } \\
\text { (industrial) } \\
\text { environment for } \\
\text { current state }\end{array} \\
\end{array}$ & - & \\
\hline $\begin{array}{c}2.3 \\
.2\end{array}$ & $\begin{array}{|lr|}\text { Complex } & \text { indicator } \\
\text { of } & \text { industrial } \\
\text { environment } & \text { for } \\
\text { current state }\end{array}$ & - & \\
\hline $\begin{array}{c}2.3 \\
.3\end{array}$ & \begin{tabular}{|lr|}
\multicolumn{3}{|c|}{ Change of complex } \\
indicator & for \\
industrial & \\
environment & \\
\end{tabular} & - & \\
\hline \begin{tabular}{|c|}
2.3 \\
.4
\end{tabular} & \begin{tabular}{|l|}
\multicolumn{3}{|c|}{ Change of complex } \\
indicator \\
natural \\
environment
\end{tabular} & - & \\
\hline \begin{tabular}{|c|}
2.3 \\
.5
\end{tabular} & $\begin{array}{|lr|}\text { Complex } & \text { indicator } \\
\text { of } & \text { natural } \\
\text { environment } & \text { for } \\
\text { future state } & \end{array}$ & & + \\
\hline \multicolumn{4}{|c|}{$\begin{array}{l}\text { Note: } \\
* \text { Calculated characteristic is based on the results of } \\
\text { calculation for the characteristics in lincs } 1.3 .1 \text { and } 1.3 .2 \text { of } \\
\text { Table } 2 \text {. } \\
\text { ** Individual (in general case) measure unit determined by } \\
\text { the nature of the indicator under consideration. } \\
\text { *** Calculated characteristic is based based on the results of } \\
\text { calculation for the characteristics } 2.3 .1-2.3 .5 \text { of Table } 2 \text {. }\end{array}$} \\
\hline
\end{tabular}

For the consciousness of the optimization model, initial data are needed (Table 1 ), for the recognition of factors of the natural and technogenic environment. In this model, the natural environment is the level of compounds in the air. 
The data on the natural environment were taken from monitoring stations located in each district of the city. Environmental indicators are industrial and municipal facilities divided by hazard classes, as well as the transport load on the motorways closest to the monitoring stations.

Environmental indicators are arithmetic mean data for each pollutant (carbon monoxide, ozone, suspended particles, etc.). The industrial environment indicators are industrial enterprises divided by hazard classes, and this also includes the transport load calculated by the arithmetic mean number of cars per hour passing through the perpendicular $\mathrm{AB}$ section on the busiest highways near monitoring stations All source data is indicated by a letter or expression for further calculations (table 1).

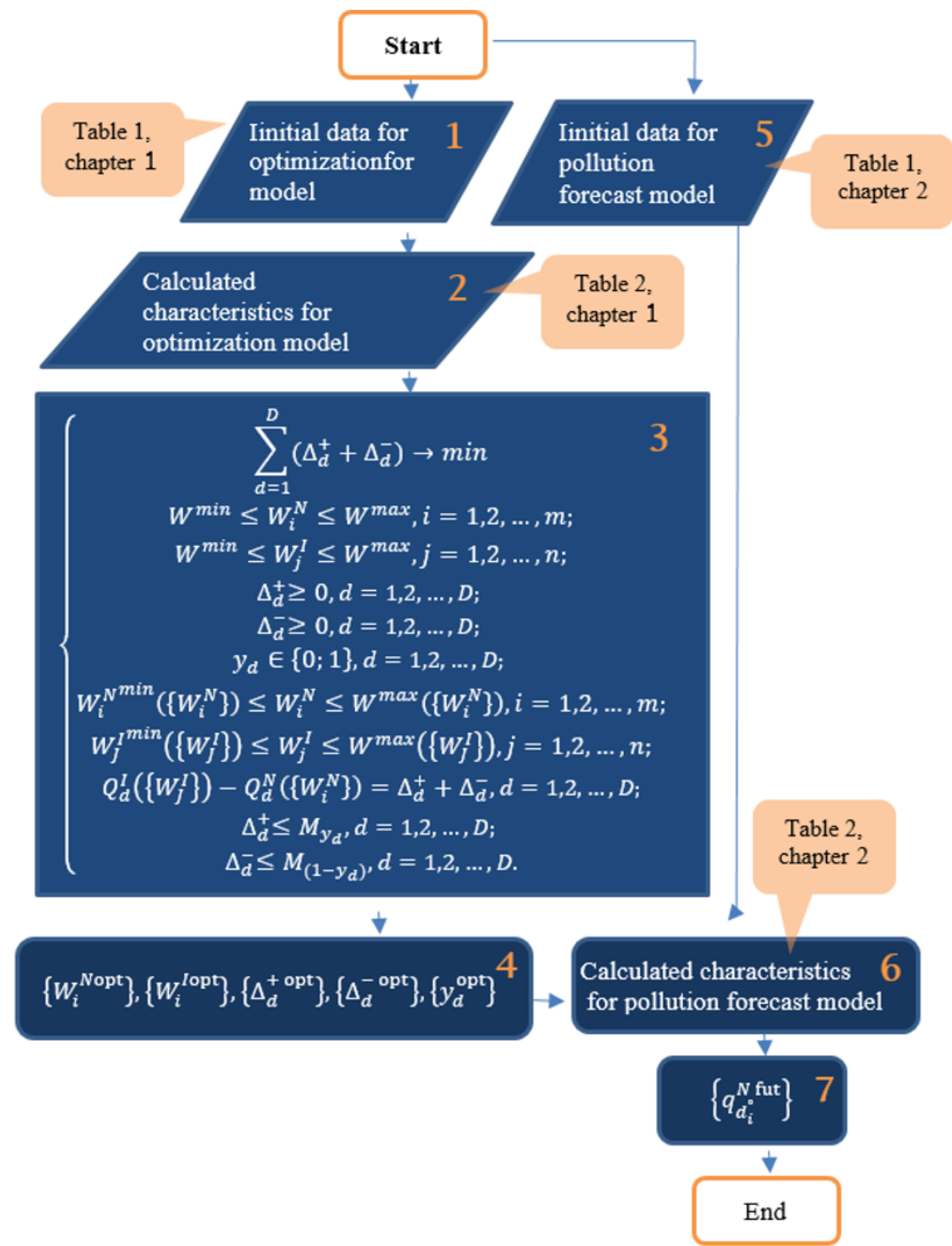

Fig. 1. Procedure for determination of predictive values for characteristics connected to assessment of environmental pollution

The essence of the mathematical model is that the quantity and quality of objects polluting the environment should correspond to the real picture obtained from monitoring stations, that is, to natural indicators. Hence, we can use this mathematical model as a predictive one, showing changes in the natural environment depending on changes in the industrial environment, finding unknowns.

Figure 1 presents a flowchart of the procedure for determining forecast values for characteristics associated with the assessment of environmental pollution, which is the result of a methodology for substantiating the characteristics of environmental pollution.

\section{Results and Discussion}

As a result of the creation of the methodology, it is possible to achieve the practical application of such a tool in the framework of monitoring and controlling the pollution of specific objects under study, for this the methodology should be implemented using standard 
computational algorithms in programs such as "Microsoft Excel”, "Mathcad", "MatLab" and others. Figures 2,3 and 4 show the application of the methodology for substantiating the characteristics of environmental pollution in Excel. Table 3 and 4 show the resulting formulas with links to the formulas in the previous figures and tables introduced in Excel to simplify the use of the model.

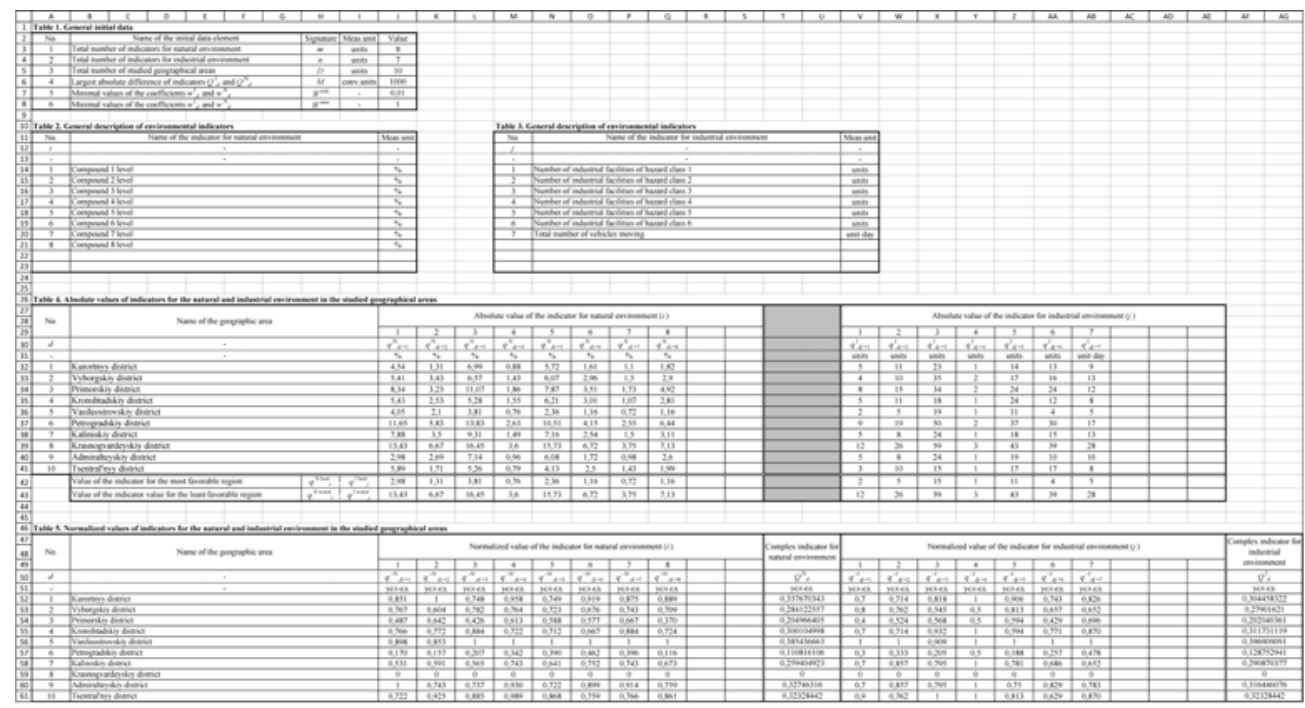

Fig.2. Initial given for the optimization model

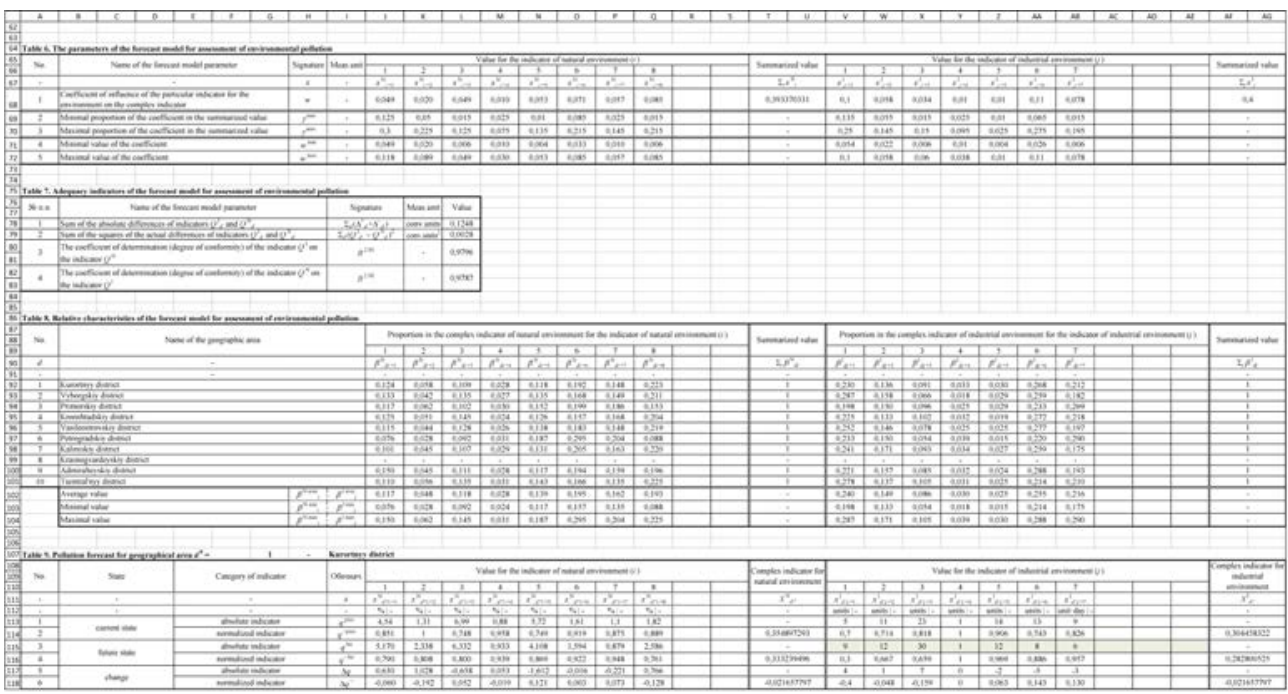

Fig.3. Calculated values of the optimization model

\begin{tabular}{|c|c|c|c|c|c|c|c|}
\hline 47 & \multicolumn{3}{|c|}{ Deviation of the indicator $Q_{\text {, from the indicator } Q^{*}}$} & \multirow{2}{*}{$\begin{array}{c}\text { Difference between positive } \\
\text { and negative absolute } \\
\text { deviations }\end{array}$} & \multirow{2}{*}{$\begin{array}{l}\text { Indicator of excess of } \\
\text { indicator } Q^{1} \text {, related to } \\
\text { indicator } Q^{N}\end{array}$} & \multirow[b]{2}{*}{$\begin{array}{l}\text { Maximal value of } \Delta^{+} \text {for a } \\
\text { positive actual deviation }\end{array}$} & \multirow[b]{2}{*}{$\begin{array}{l}\text { Maximal value of } \Delta^{\prime \prime} \text { for a } \\
\text { negative actual deviation }\end{array}$} \\
\hline 48 & actual & absolute positive & absolute negative & & & & \\
\hline 50 & $Q_{d}^{i}-Q_{d}^{N}$ & $\Delta_{d}^{*}$ & $\Delta_{d}$ & $\Delta_{d}^{*}-\Delta_{d}^{-}$ & $y_{d}$ & $M \cdot y_{d}$ & $M \cdot\left(1-y_{d}\right)$ \\
\hline 51 & yerea & уелеа & ycaer & уелед & $\cdot$ & услет. & yeaer \\
\hline 52 & $-0,03321202 \mid$ & 0 & 0,033212021 & -0.033212021 & 0 & 0 & 1000 \\
\hline 53 & $-0,005106347$ & 0 & 0.005106347 & -0.005106347 & 0 & 0 & 1000 \\
\hline 54 & $-0,002926044$ & 0 & 0,002926044 & $-0,002926044$ & 0 & 0 & 1000 \\
\hline 55 & 0,011626122 & 0,011626122 & 0 & 0,011626122 & 1 & 1000 & 0 \\
\hline 56 & 0,011472428 & 0,011472428 & 0 & 0,011472428 & 1 & 1000 & 0 \\
\hline 57 & 0,017936835 & 0,017936835 & 0 & 0,017936835 & 1 & 1000 & 0 \\
\hline 58 & 0,031465454 & 0,031465454 & 0 & 0,031465454 & 1 & 1000 & 0 \\
\hline 59 & 0 & 0 & 0 & 0 & 0 & 0 & 1000 \\
\hline 60 & $-0,011017084$ & 0 & 0,011017084 & $-0,011017084$ & 0 & 0 & 1000 \\
\hline
\end{tabular}

Fig.4. Calculated characteristics for pollution forecast model

Table 3. Principles of worksheet formation in "Microsoft Excel" software

\begin{tabular}{|l|l|l|}
\hline $\begin{array}{l}\text { Address } \\
\text { of } \\
\text { cell(s) }\end{array}$ & $\begin{array}{l}\text { "Microsoft Excel” formula / } \\
\text { comment }\end{array}$ & $\begin{array}{l}\text { Optimization } \\
\text { model } \\
\text { element }\end{array}$ \\
\hline Table 1 & \multicolumn{2}{|l|}{} \\
\hline J3 & value of initial data element & $\begin{array}{l}\text { Table 1, line } \\
1.1 .1 .1\end{array}$ \\
\hline J4 & value of initial data element & $\begin{array}{l}\text { Table 1, line } \\
1.1 .1 .2\end{array}$ \\
\hline
\end{tabular}

\begin{tabular}{|l|l|l|}
\hline J5 & value of initial data element & $\begin{array}{l}\text { Table } 1 \text {, line } \\
1.1 .1 .3\end{array}$ \\
\hline \multirow{2}{*}{ 6 } & value of initial data element & $\begin{array}{l}\text { Table } 1 \text {, line } \\
1.1 .1 .4\end{array}$ \\
\hline \multirow{2}{*}{ J7 } & value of initial data element & $\begin{array}{l}\text { Table } 1 \text {, line } \\
1.1 .1 .5\end{array}$ \\
\hline \multirow{2}{*}{ J8 } & value of initial data element & $\begin{array}{l}\text { Table } 1 \text {, line } \\
1.1 .1 .6\end{array}$ \\
\hline Table 2 & \multicolumn{2}{|l}{} \\
\hline \multirow{2}{*}{ B14:I21 } & values of initial data elements & $\begin{array}{l}\text { Table } 1 \text {, line } \\
1.1 .2 .1\end{array}$ \\
\hline
\end{tabular}




\begin{tabular}{|c|c|c|}
\hline \multicolumn{3}{|l|}{ Table 3} \\
\hline B14:I21 & values of initial data elements & \begin{tabular}{|l} 
Table 1, line \\
1.1.2.1
\end{tabular} \\
\hline \multicolumn{3}{|l|}{ Table 4} \\
\hline B32:I41 & values of initial data elements & \begin{tabular}{|l} 
Table 1, line \\
1.1.3.1
\end{tabular} \\
\hline J32:Q41 & values of initial data elements & \begin{tabular}{|l} 
Table 1, line \\
1.1.4.1
\end{tabular} \\
\hline $\begin{array}{l}\text { V32:AB } \\
41\end{array}$ & values of initial data elements & \begin{tabular}{|l} 
Table 1, line \\
1.1.4.1
\end{tabular} \\
\hline $\begin{array}{l}\mathrm{J} 42(: \mathrm{S} 4 \\
2)\end{array}$ & $\begin{array}{l}=I F(J 29<>\text { "';MIN(OFFSET(J32; } \\
\text {;;\$J\$5;));"') }\end{array}$ & \begin{tabular}{|l|} 
Table 2, line \\
1.3 .1 \\
\end{tabular} \\
\hline $\begin{array}{l}\text { V42(:A } \\
\text { E42) }\end{array}$ & $\begin{array}{l}=\mathrm{IF}(\mathrm{V} 29<>+" ' ; \mathrm{MIN}(\mathrm{OFFSET}(\mathrm{V} 3 \\
\text { 2;;;\$J\$5;));"') }\end{array}$ & \begin{tabular}{|l|} 
Table 2, line \\
1.3 .1 \\
\end{tabular} \\
\hline $\begin{array}{l}\mathrm{J} 43(: \mathrm{S} 4 \\
3)\end{array}$ & $\begin{array}{l}=\mathrm{IF}(\mathrm{J} 29<>+" ' ; \mathrm{MAX}(\mathrm{OFFSET}(\mathrm{J} 32 \\
; ; ; \$ \mathrm{~J} \$ 5 ;)) ; " ')\end{array}$ & \begin{tabular}{|l|} 
Table 2, line \\
1.3 .2
\end{tabular} \\
\hline $\begin{array}{l}\text { V43(:A } \\
\text { E43) }\end{array}$ & $\begin{array}{l}=\mathrm{IF}(\mathrm{V} 29<>\text { "'";MAX(OFFSET(V } \\
\text { 32;;;\$J5;));"') }\end{array}$ & \begin{tabular}{|l|} 
Table 2, line \\
1.3 .2 \\
\end{tabular} \\
\hline \multicolumn{3}{|c|}{ Table 5} \\
\hline $\begin{array}{l}\text { J52(:S6 } \\
1)\end{array}$ & $\begin{array}{l}=\mathrm{IF}(\text { И(\$A52<>""';J \$49<>"'"); } \\
\text { (J32-J\$43)/(Ј\$42-J\$43);"'") }\end{array}$ & \begin{tabular}{|l|} 
Table 2, line \\
1.1 .1 \\
\end{tabular} \\
\hline $\begin{array}{l}\text { T52(:U6 } \\
1)\end{array}$ & $\begin{array}{l}\text { =IF(A52<>"'";SUMPRODUCT( } \\
\text { OFFSET(J52;;;;\$J3);OFFSET(\$ } \\
\text { J\$68;;;;\$J\$));"') }\end{array}$ & $\begin{array}{l}\text { Table 2, line } \\
1.2 .1\end{array}$ \\
\hline $\begin{array}{l}\text { V52(:A } \\
\text { E61) }\end{array}$ & 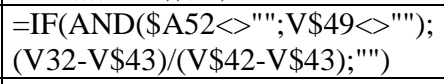 & \begin{tabular}{|l|} 
Table 2, line \\
1.1 .1 \\
\end{tabular} \\
\hline $\begin{array}{l}\text { AF52(: } \\
\text { AG61) }\end{array}$ & $\begin{array}{l}\text { =IF(A52<>"'";SUMPRODUCT( } \\
\text { OFFSET(V52;;;;\$J\$);OFFSET( } \\
\text { \$V\$68;;;;\$J4));"') }\end{array}$ & $\begin{array}{l}\text { Table 2, line } \\
1.2 .1\end{array}$ \\
\hline $\begin{array}{l}\text { AH52(: } \\
\text { AH61) }\end{array}$ & $=\mathrm{AF} 52-\mathrm{T} 52$ & $\begin{array}{l}\text { Figure 1, } \\
\text { block 3, line } \\
\text { 9, left part of } \\
\text { expression } \\
\end{array}$ \\
\hline $\begin{array}{l}\text { AI52:AJ } \\
61\end{array}$ & values of unknown variables & \begin{tabular}{|l|} 
Table 1, line \\
2.2
\end{tabular} \\
\hline $\begin{array}{l}\text { AK52(: } \\
\text { AK61) }\end{array}$ & $=\mathrm{AI} 52-\mathrm{AJ} 52$ & $\begin{array}{l}\text { Figure 1, } \\
\text { block 3, line } \\
\text { 9, right part } \\
\text { of expression }\end{array}$ \\
\hline $\begin{array}{l}\text { AL52:A } \\
\text { L61 }\end{array}$ & values of unknown variables & \begin{tabular}{|l|} 
Table 1, line \\
2.3 \\
\end{tabular} \\
\hline $\begin{array}{l}\text { AM52(: } \\
\text { AM61) }\end{array}$ & $=\$ \mathrm{~J} \$ 6 * \mathrm{AL} 52$ & $\begin{array}{l}\text { Figure 1, } \\
\text { block 3, line } \\
\text { 10, right part } \\
\text { of expression } \\
\end{array}$ \\
\hline $\begin{array}{l}\text { AN52(: } \\
\text { AN61) }\end{array}$ & $=\$ J \$ 6 *(1-A L 52)$ & $\begin{array}{l}\text { Figure 1, } \\
\text { block 3, line } \\
\text { 11, right part } \\
\text { of expression }\end{array}$ \\
\hline \multicolumn{3}{|l|}{ Table 6} \\
\hline J68:S68 & values of unknown variables & \begin{tabular}{|l} 
Table 1, line \\
2.1
\end{tabular} \\
\hline T68 & $=$ SUM(OFFSET( $(\$$ J $\$ 68 ; ; ; ; \$ J \$ 3))$ & - \\
\hline $\begin{array}{l}\text { V68:AE } \\
68 \\
\end{array}$ & values of unknown variables & \begin{tabular}{|l}
$\begin{array}{l}\text { Table 1, line } \\
2.1\end{array}$ \\
\end{tabular} \\
\hline AF68 & $=$ SUM(OFFSET $(\$ V \$ 68 ; ; ; ;$ J $\$ 4))$ & - \\
\hline J69:S69 & values of initial data elements & \begin{tabular}{|l} 
Table 1, line \\
1.1.2.2
\end{tabular} \\
\hline $\begin{array}{l}\text { V69:AE } \\
69\end{array}$ & values of initial data elements & \begin{tabular}{|l|} 
Table 1, line \\
1.1 .2 .2
\end{tabular} \\
\hline J70:S70 & values of initial data elements & \begin{tabular}{|l} 
Table 1, line \\
1.1.2.3
\end{tabular} \\
\hline $\begin{array}{l}\text { V70:AE } \\
70\end{array}$ & values of initial data elements & \begin{tabular}{|l} 
Table 1, line \\
1.1.2.3
\end{tabular} \\
\hline $\begin{array}{l}\text { J71(:S7 } \\
1)\end{array}$ & $=\mathrm{IF}(\mathrm{J} \$ 66<>$ "';\$T\$68*J69;"'") & \begin{tabular}{|l|} 
Table 2, line \\
1.3 .3 \\
\end{tabular} \\
\hline $\begin{array}{l}\text { V71(:A } \\
\text { E71) }\end{array}$ & $=\mathrm{IF}(\mathrm{V} \$ 66<>$ "';\$AF\$68*V69;"') & \begin{tabular}{|l|} 
Table 2, line \\
1.3 .3
\end{tabular} \\
\hline
\end{tabular}

\begin{tabular}{|c|c|c|}
\hline $\begin{array}{l}\text { J72(:S7 } \\
2)\end{array}$ & =IF(J\$66<>"'";T\$68*J70;"'") & \begin{tabular}{|l|} 
Table 2, line \\
1.3.4
\end{tabular} \\
\hline \begin{tabular}{|l|} 
V72(:A \\
E72) \\
\end{tabular} & =IF(V\$66<>"';\$AF\$68*V70;"') & $\begin{array}{l}\text { Table 2, line } \\
1.3 .4 \\
\end{array}$ \\
\hline \multicolumn{3}{|l|}{\begin{tabular}{|l|} 
Table 7 \\
\end{tabular}} \\
\hline L78 & $=$ SUM(OFFSET(AI52;;;J5;2)) & $\begin{array}{l}\text { Figure 1, } \\
\text { block 3, line } \\
\text { 1, left part of } \\
\text { expression } \\
\end{array}$ \\
\hline L79 & $\begin{array}{l}=\text { SUMXMY2(OFFSET(T52;;;J5; } \\
\text { ); } \\
\text { OFFSET(AF52;;;J5;)) }\end{array}$ & - \\
\hline L80 & $\begin{array}{l}=\text { IF(NOT(ISERROR( } \\
\text { 1- } \\
\text { L79/(VAR.S(OFFSET(T52;;;J5;) } \\
\text { )*J5))); } \\
\text { 1- } \\
\text { L79/(VAR.S(OFFSET(T52;;;J5;) } \\
\text { )*J5);"-") }\end{array}$ & $\begin{array}{l}\text { Table 2, line } \\
1.4 .1\end{array}$ \\
\hline L82 & $\begin{array}{l}\text { =IF(NOT(ISERROR( } \\
\text { 1- } \\
\text { L79/(VAR.S(OFFSET(AF52;;;J5 } \\
\text {;))*J5))); } \\
\text { 1- } \\
\text { L79/(VAR.S(OFFSET(AF52;;;J5 } \\
\text {;))*J5);"-") }\end{array}$ & $\begin{array}{l}\text { Table 2, line } \\
1.4 .1\end{array}$ \\
\hline \multicolumn{3}{|l|}{ Table 8} \\
\hline $\begin{array}{l}\mathrm{J} 92(: \mathrm{S} 1 \\
01)\end{array}$ & $\begin{array}{l}\text { =IF(AND(\$A92<>"';J\$89<>"'");I } \\
\text { F(\$T52>0; } \\
\text { J52*J\$68/\$T52;"-");"'") }\end{array}$ & $\begin{array}{l}\text { Table 2, line } \\
2.1 .1\end{array}$ \\
\hline \begin{tabular}{|l|} 
T92(:U1 \\
$01)$
\end{tabular} & $\begin{array}{l}=\mathrm{IF}(\mathrm{A} 92<>\text { "'";IF(T52>0;SUM(O } \\
\text { FFSET(J92;;;;\$J\$3)); } \\
\text { "-");"'") }\end{array}$ & - \\
\hline $\begin{array}{l}\text { V92(:A } \\
\text { E101) }\end{array}$ & $\begin{array}{l}=\mathrm{IF}(\mathrm{AND}(\$ \mathrm{~A} 92<>+" ; \mathrm{V} \$ 89<>" ' ") ; \\
\text { IF(\$AF52>0;V52*V\$68/\$AF52;" } \\
\text {-");"') }\end{array}$ & $\begin{array}{l}\text { Table 2, line } \\
2.1 .1\end{array}$ \\
\hline $\begin{array}{l}\text { AF92(: } \\
\text { AG101) }\end{array}$ & $\begin{array}{l}\text { =IF(M92<>"';IF(AF52>0; } \\
\text { SUM(OFFSET(V92;;;;\$J\$));"- } \\
\text { ");"') }\end{array}$ & - \\
\hline \begin{tabular}{|l|}
$\mathrm{J} 102(: \mathrm{S}$ \\
$102)$ \\
\end{tabular} & $\begin{array}{l}=\text { IF(J\$89<>"'";AVERAGE(OFFS } \\
\text { ET(J\$92;;;\$J\$5;));"') }\end{array}$ & \begin{tabular}{|l|} 
Table 2, line \\
2.2 .1 \\
\end{tabular} \\
\hline $\begin{array}{l}\text { V102(: } \\
\text { AE102) }\end{array}$ & $\begin{array}{l}=\text { IF(V\$89<>"';;AVERAGE(OFF } \\
\text { SET(V\$92;;;\$J5;)); } \\
\text { "'") }\end{array}$ & $\begin{array}{l}\text { Table 2, line } \\
2.2 .1\end{array}$ \\
\hline \begin{tabular}{|l|}
$\mathrm{J} 103(: \mathrm{S}$ \\
$103)$ \\
\end{tabular} & $\begin{array}{l}=\mathrm{IF}(\mathrm{J} \$ 89<>+" ' ; \mathrm{MIN}(\mathrm{OFFSET}(\mathrm{J} \$ 9 \\
\text { 2;;;\$J5;));"') }\end{array}$ & $\begin{array}{l}\text { Table 2, line } \\
2.2 .2 \\
\end{array}$ \\
\hline \begin{tabular}{|l|} 
V103(: \\
AE103) \\
\end{tabular} & $\begin{array}{l}=\mathrm{IF}(\mathrm{V} \$ 89<>+" ' ; \mathrm{MIN}(\mathrm{OFFSET}(\mathrm{V} \\
\$ 92 ; ; ; \$ \mathrm{~J} \$ 5 ;)) ; " ')\end{array}$ & \begin{tabular}{|l|} 
Table 2, line \\
2.2 .2 \\
\end{tabular} \\
\hline \begin{tabular}{|l|} 
J104(:S \\
$104)$ \\
\end{tabular} & $\begin{array}{l}=\mathrm{IF}(\mathrm{J} \$ 89<>" ' ; \text { MAX(OFFSET(J\$ } \\
\text { 92;;;\$J\$5;));"') }\end{array}$ & \begin{tabular}{|l|} 
Table 2, line \\
2.2 .3 \\
\end{tabular} \\
\hline \begin{tabular}{|l|} 
V104(: \\
AE104) \\
\end{tabular} & $\begin{array}{l}\text { =IF(V\$89<>"'";MAX(OFFSET( } \\
\text { V\$92;;;\$J\$5;));"'") }\end{array}$ & \begin{tabular}{|l} 
Table 2, line \\
2.2 .3 \\
\end{tabular} \\
\hline \multicolumn{3}{|l|}{ Table 9} \\
\hline G107 & value of initial data element & $\begin{array}{l}\text { Table 1, line } \\
1.2 .1\end{array}$ \\
\hline \begin{tabular}{|l|} 
J113:Q1 \\
13 \\
\end{tabular} & values of initial data elements & \begin{tabular}{|l|} 
Table 1, line \\
1.2 .2 \\
\end{tabular} \\
\hline \begin{tabular}{|l|} 
V113:A \\
B113 \\
\end{tabular} & values of initial data elements & \begin{tabular}{|l|} 
Table 1 , line \\
1.2 .2 \\
\end{tabular} \\
\hline $\begin{array}{l}\mathrm{J} 114(: \mathrm{S} \\
114)\end{array}$ & $\begin{array}{l}\text { =IF(NOT(ISERROR( } \\
\text { VLOOKUP(\$G } 107 ; \$ A 52: \$ A E \\
\text { \$61;9+J\$110))); } \\
\text { VLOOKUP(\$G\$107;\$A \$52:\$AE } \\
\text { \$61;9+J\$110);"') }\end{array}$ & $\begin{array}{l}\text { Table 2, line } \\
2.2 .4\end{array}$ \\
\hline T114 & 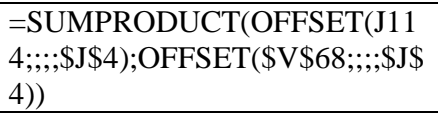 & $\begin{array}{l}\text { Table 2, line } \\
\text { 2.3.1 }\end{array}$ \\
\hline
\end{tabular}




\begin{tabular}{|c|c|c|}
\hline $\begin{array}{l}\text { V114(: } \\
\text { AE114) }\end{array}$ & $\begin{array}{l}\text { =IF(NOT(ISERROR( } \\
\text { VLOOKUP(\$G } 107 ; \$ A 52: \$ A E \\
\text { \$61;21+V \$110)); } \\
\text { VLOOKUP(\$G\$107;\$A \$52:\$AE } \\
\text { \$61;21+V\$110);"') }\end{array}$ & $\begin{array}{l}\text { Table 2, line } \\
2.2 .4\end{array}$ \\
\hline AF114 & $\begin{array}{l}=\text { SUMPRODUCT(OFFSET(V11 } \\
4 ; ; ; ; \$ \text { J } 4) ; \\
\text { OFFSET }(\$ V \$ 68 ; ; ; ; \$ J 4))\end{array}$ & $\begin{array}{l}\text { Table 2, line } \\
2.3 .1\end{array}$ \\
\hline $\begin{array}{l}\mathrm{J} 115(: \mathrm{S} \\
115)\end{array}$ & $\begin{array}{l}\text { =IF(J110<>"'";J116*(J42- } \\
\text { J43)+J43;"'") }\end{array}$ & \begin{tabular}{|l|} 
Table 2, line \\
2.2 .9 \\
\end{tabular} \\
\hline $\begin{array}{l}\text { V115:A } \\
\text { B115 }\end{array}$ & values of initial data elements & \begin{tabular}{|l|} 
Table 1, line \\
1.2 .3 \\
\end{tabular} \\
\hline $\begin{array}{l}\mathrm{J} 116(: \mathrm{S} \\
116)\end{array}$ & $\begin{array}{l}=\mathrm{IF}(\mathrm{J} \$ 110<>" ' ; \$ \mathrm{~T} \$ 116 * J 102 / \mathrm{J} 6 \\
8 ; " ')\end{array}$ & \begin{tabular}{|l|} 
Table 2, line \\
2.2 .8 \\
\end{tabular} \\
\hline T116 & $=\mathrm{T} 114+\mathrm{T} 118$ & \begin{tabular}{|l} 
Table 2, line \\
2.3.5
\end{tabular} \\
\hline $\begin{array}{l}\text { V116(: } \\
\text { AE116) }\end{array}$ & $\begin{array}{l}0<>" ' ; \mathrm{IF}(\mathrm{V} \$ 66<>+" ' ; \\
\$ 43) /(\mathrm{V} \$ 42- \\
; " '+)\end{array}$ & $\begin{array}{l}\text { Table 2, line } \\
2.2 .5\end{array}$ \\
\hline AF116 & $\begin{array}{l}\text { =SUMPRODUCT(OFFSET(V11 } \\
\text { 6;;;;\$J4); } \\
\text { OFFSET(\$V\$68;;;;\$J4)) }\end{array}$ & $\begin{array}{l}\text { Table 2, line } \\
2.3 .2\end{array}$ \\
\hline $\begin{array}{l}J 117(: S \\
117)\end{array}$ & =IF(J\$110<>"'";J115-J113;"'") & \begin{tabular}{|l} 
Table 2, line \\
2.2 .6
\end{tabular} \\
\hline $\begin{array}{l}\text { V117(: } \\
\text { AE117) }\end{array}$ & =IF(V\$110<>"'";V115-V113;"'") & \begin{tabular}{|l|} 
Table 2, line \\
2.2.6 \\
\end{tabular} \\
\hline $\begin{array}{l}\mathrm{J} 118(: \mathrm{S} \\
118)\end{array}$ & =IF(J\$110<>"'";J116-J114;"'") & \begin{tabular}{|l|} 
Table 2, line \\
2.2 .7 \\
\end{tabular} \\
\hline T118 & $=\mathrm{AF} 118$ & \begin{tabular}{|l} 
Table 2, line \\
2.3 .4
\end{tabular} \\
\hline $\begin{array}{l}\text { V118(: } \\
\text { AE118) }\end{array}$ & =IF(V\$110<>"';/V116-V114;"') & \begin{tabular}{|l} 
Table 2, line \\
2.2 .7
\end{tabular} \\
\hline AF118 & $=\mathrm{AF} 116-\mathrm{AF} 114$ & \begin{tabular}{|l} 
Table 2, line \\
2.3 .5
\end{tabular} \\
\hline
\end{tabular}

Table 4. Values of "Solver" add-in setting parameters for created procedure

\begin{tabular}{|c|c|c|}
\hline $\begin{array}{l}\text { "Solver" setting } \\
\text { parameter }\end{array}$ & Parameter value & $\begin{array}{l}\text { Procedure } \\
\text { element }\end{array}$ \\
\hline Objective cell & L78 & \multirow{2}{*}{$\begin{array}{l}\text { Figure 1, block } \\
\text { 3, line } 1\end{array}$} \\
\hline \begin{tabular}{|l|} 
Type of \\
optimization \\
problem
\end{tabular} & Minimum & \\
\hline \multirow{4}{*}{$\begin{array}{l}\text { By changing } \\
\text { variable cells }\end{array}$} & J68:Q68; & Table 1, line 2.1 \\
\hline & V68:AB68; & Table 1, line 2.1 \\
\hline & AI52:AJ61; & Table 1 , line 2.2 \\
\hline & AL52:AL61 & Table 1 , line 2.2 \\
\hline \multirow[t]{12}{*}{ Constraints } & J68:Q68 >= J7; & \multirow{2}{*}{$\begin{array}{l}\text { Figure 1, block } \\
3 \text {, line } 2\end{array}$} \\
\hline & J68:Q68 <= J8; & \\
\hline & V68:AB68 >= J7; & \multirow{2}{*}{$\begin{array}{l}\text { Figure 1, block } \\
3 \text {, line } 3\end{array}$} \\
\hline & V68:AB68 <= J8; & \\
\hline & AI52:AJ61 >= 0; & $\begin{array}{l}\text { Figure } 1 \text {, block } \\
3 \text {, lines } 4,5\end{array}$ \\
\hline & $\begin{array}{l}\text { AI52:AJ61 = } \\
\text { binary; }\end{array}$ & $\begin{array}{l}\text { Figure 1, block } \\
3 \text {, line } 6\end{array}$ \\
\hline & $\begin{array}{l}\text { J68:Q68 >= } \\
\text { J71:Q71; }\end{array}$ & \multirow[t]{2}{*}{$\begin{array}{l}\text { Figure } 1 \text {, block } \\
3 \text {, line } 7\end{array}$} \\
\hline & $\begin{array}{l}\mathrm{J} 68: Q 68<= \\
\text { J72:Q72; }\end{array}$ & \\
\hline & $\begin{array}{l}\text { V68:AB68 >= } \\
\text { V71:AB71; }\end{array}$ & \multirow[t]{2}{*}{$\begin{array}{l}\text { Figure 1, block } \\
3 \text {, line } 8\end{array}$} \\
\hline & $\begin{array}{l}\text { V68:AB68 <= } \\
\text { V72:AB72; }\end{array}$ & \\
\hline & $\begin{array}{l}\text { AH52:AH61 = } \\
\text { AK52:AK61; }\end{array}$ & $\begin{array}{l}\text { Figure } 1 \text {, block } \\
3 \text {, line } 9\end{array}$ \\
\hline & $\begin{array}{l}\text { AI52:AI61 <= } \\
\text { AM52:AM61; }\end{array}$ & $\begin{array}{l}\text { Figure } 1 \text {, block } \\
3 \text {, line } 10\end{array}$ \\
\hline
\end{tabular}

\begin{tabular}{|l|l|l|}
\hline & $\begin{array}{l}\text { AJ52:AJ61 <= } \\
\text { AN52:AN61 }\end{array}$ & Figure 1, block \\
3, line 11 \\
\hline Solving method & Simplex LP & \\
\hline
\end{tabular}

A distinctive feature of this model is the linear nature of the relationship of nonlinear variables, that is, regression models with the optimality criterion - the sum of the squares of the absolute deviations of the predicted values of the complex indicator. A comprehensive indicator is an indicator of pollution for a given dataset of natural and industrial environments.

If this model is applied in practice, it is possible to obtain a program that analyzes the current state of the environment, depending on the quantity and quality of technogenic factors. Also, as a result of changes in quantitative indicators, this model will indicate critical changes in the natural environment.

\section{Conclusions}

A methodology was developed to justify the characteristics of environmental pollution, the result of which is a flowchart of the procedure for determining forecast values for the characteristics associated with the assessment of environmental pollution. Based on this technique, a model was obtained for predicting the pollution of the city, a distinctive feature of which is to separately account for the influence of factors of the natural and industrial environment, as well as the linear nature of the relationship of unknown variables representing the parameters of the regression model with the optimality criterion, which is the sum of the squares of the absolute deviation of the value a complex indicator of pollution for a given set of parameters of both considered environments. This model, to simplify working with it, was introduced into Microsoft Excel for automatic calculations according to given formulas and obtained indicators of the natural and technogenic environment.

Obviously, the resulting model will allow us to analyze the current state of the environment depending on the quantity and quality of environmental indicators, as well as determine critical changes in it. In the urban development industry, this model will help in planning the possibility of placing objects with a high environmental burden in a particular area. Also, in the case of finalizing this model, it is possible to predict the security measures taken, depending on the level of increase in the pollution indicator, taking into account certain factors.

\section{References}

1. Pereira, Norman \& Hung, Yung-Tse. (2004). Air Pollution Control Engineering. 10.1007/978-159259-778-9.

2. Gulia, S., et al., Urban air quality management-A review. Atmospheric Pollution Research 6(2) 286304 (2015)

3. E. Voskresenckaya, L. Vorona-Slivinskaya, Y. Tilinin, E3S Web of Conferences 11008014 (2019) 
4. Chu, A.K.M., R.C.W. Kwok, and K.N. Yu, Study of pollution dispersion in urban areas using Computational Fluid Dynamics (CFD) and Geographic Information System (GIS). Environmental Modelling \& Software 20(3) 273-277 (2005)

5. Adams, M.D. and P.S. Kanaroglou, Mapping realtime air pollution health risk for environmental management: Combining mobile and stationary air pollution monitoring with neural network models. Journal of Environmental Management 168 133141 (2016)

6. Zaikanov V.G., Minakova T.B., Buldakova E.V. Theoretical principles and methodical approaches to urban area zoning by geoecological restrictions. Water resources 44 987-994 (2017)

7. E. Ruskin, A. Moron, K. Smirnov, V. Davydov, V. Yushkova, MATEC Web of Conference 245 12002 (2018)

8. N. Grebenikova, V. Davydov, A. Moroz, M. Burina, M. Kuzmin, IOP Conference Series: Materials Science and Engineering 497012109 (2019)

9. N. Myazin, V. Davidov, V. Yushakova, V.Rud, Journal of Environmental Research, Engineering and Management 75/2 (2019)

10. WHO, Ambient air pollution: A global assessment of exposure and burden of disease, W.H. Organization, Editor. (2016)

11. M. Kampa, E. Castanas, Human Health Effects of Air Pollution, Environ. Pollut. 151(2) 362-367 (2008)

12. Y. Cartier, T. Benmarhnia, and A. Brousselle, Tool for assessing health and equity impacts of interventions modifying air quality in urban environments. Evaluation and Program Planning 53 1-9 (2015)

13. Zhong, J., X.-M. Cai, and W.J. Bloss, Coupling dynamics and chemistry in the air pollution modelling of street canyons: A review. Environmental Pollution 214 690-704 (2016)

14. E. Diapouli, , et al., Evolution of air pollution source contributions over one decade, derived by PM10 and PM2.5 source apportionment in two metropolitan urban areas in Greece. Atmospheric Environment (2017)

15. A. McNabola, B.M. Broderick, and L.W. Gill, A numerical investigation of the impact of low boundary walls on pedestrian exposure to air pollutants in urban street canyons. Science of The Total Environment 407(2) 760-769 (2009)

16. F. Nejadkoorki, and S. Baroutian, Forecasting Extreme PM10 Concentrations Using Artificial Neural Networks. International Journal of Environmental Research 6(1) 277-284 (2012)

17. R. Atkinson, Atmospheric chemistry of VOCs and NO x. Atmospheric environment 34(12) 20632101 (2000)

18. K.-H. Kim, E. Kabir, and S. Kabir, A review on the human health impact of airborne particulate matter. Environment international 74 136-143 (2015)

19. R.V. Martin, Satellite remote sensing of surface air quality. Atmospheric Environment 42(34) 78237843 (2008)

20. B. Rashid, and M.H. Rehmani, Applications of wireless sensor networks for urban areas: A survey. Journal of Network and Computer Applications 60 192-219 (2016)

21. M. Sammarco, et al., Using geosocial search for urban air pollution monitoring. Pervasive and Mobile Computing 35 15-31 (2017)

22. S.S. Bachurina, V.L. Belyaev, E.A. Karfidova Geoecological Aspects of the Development of a Regional Model of Spatial Planning: Case Study of Moscow. Water Resources 44 978-986 (2017)

23. P. Neofytou et al., Computational Fluid Dynamics Modelling of the Pollution Dispersion and Comparison with Measurements in a Street Canyon in Helsinki. Environmental Modeling \& Assessment, 13(3) 439- 448 (2008)

24. A. Baklanov, Application of CFD Methods for Modelling in Air Pollution Problems: Possibilities and Gaps. Environmental Monitoring and Assessment, 65(1) 181-189 (2000)

25. L.K. Wang, N.C. Pereira, Y. Hung, Air Pollution Control Engineering, in Handbook of Environmental Engineering, Vol 1, Humana Press, Totowa, NJ 7-10 (2004)

26. M. Fedorov, V. Badenko, A. Chusov, M. Maskikov, E3S Web of Conferences 9107001 (2019)

27. M. Bolsunovskaya, A. Leksashov, A. Loginova, S. Shirokova, E3S Web of Conferences 9107011 (2019) 